\title{
載荷方法が花崗岩のカイザー効果に及ぼす影響
}

\section{THE KAISER EFFECT OF GRANITE CAUSED BY VARIOUS LOADING METHODS}

\author{
村山朔 郎*·道広一利**・斉藤二郎***. 吉 岡 尚也**** \\ By Sakuro MURA YAMA, Kazutoshi MICHIHIRO, Jiro SAITO and Hisaya YOSHIOKA
}

\begin{abstract}
In order to know the Kaiser effect of $\mathrm{AE}$ (Acoustic Emission) in triaxial directions of a rock mass, the Kaiser effect of $\mathrm{AE}$ in the granite specimens were investigated by applying the compressive pre-stresses of various intensities repeatedly on the respective directions to the specimens.

From the testing results, it was found that the pre-compressed principal stresses were precisely estimated by the Kaiser effect, provided the specimens had been repeatedly pre-compressed until the increment of the residual strain ceased.
\end{abstract}

\section{1. はじめに}

岩盤に対するアコースティック・エミッション (Acoustic Emission 以下 AE と記す) は，主に鉱山に おける切羽の安定性を研究することから始められた. Obert ら"1) は, 鉱山における山はねを予知するために, 1940 年代前半から AE の観測を行っていた. 1953 年に は, Kaiser ${ }^{2)}$ は金属材料において AE の発生が先に加え た応力以上，すなわち先行応力以上の応力下で発生する ことを見出した。これがよく知られている Kaiser effect (カイザー効果) である．岩石に繰返し応力を与えた場 合にも, カイザー効果が存在することは Goodman ${ }^{3)} に$ よって確認されている。また，金川ら ${ }^{4)}$ は原位置から採 取した岩石供試体に単調に増加する応力を与えて, その ときの $\mathrm{AE}$ 累積曲線の変曲点で先行応力を推定してい る.この先行応力は, オーバーコアリング法から求めた 地圧に比して十数パーセントの誤差範囲で推定できるこ

* 正会員 工博 京都大学名誉教授 ( ( 603 京都市北区紫竹上梅/木町 26)

** 正会員 工修 摄南大学講師 工学部土木工学科 ( 572 大阪府寝屋川市池田中町 17-8)

*** 正会員 工博 (株) 大林組技術研究所次長 （解 204 清瀬市下清戸 $4-640$ )

**** 正会員 工修 (株) 大林組技術研究所研究員 (同上)
とを述べている.

本報文は岩石として花崗岩を用い，その $\mathrm{AE}$ のイ ザー効果に関して研究した報告である. 本研究の意図す るところは, 第 1 には, 岩石における AEのカイザー 効果は先行して岩石に加えられた応力值そのものに依存 するよりは，むしろ先行応力によって岩石に生じたひず みのうち $\mathrm{AE}$ 試験時に残留している残留ひずみに依存 すると考えられたことを実験的に検証することであり， 第 2 には，空間に互いに直行する 3 方向の面のうち，あ る方向の面に対するカイザー効果が，他の方向の各面に 別々に加えられた先行軸応力とどのような関係にあるか を実験的に明らかにすることである。

\section{2. 実験試料と実験装置および実験方法}

実験に用いた試料は生駒産と稲田産の 2 種類で, 生駒 産は約 $250 \mathrm{~m}$ の土被りを有するトンネル建設現場から 採取し, 稲田産は約 $300 \mathrm{~m}$ の土被りを有していた切取 地あとから大塊の岩塊として切り出した。これらの大塊 の岩石をさらにのみで小割りし，それを供試体に仕上げ た. 供試体の形状・寸法は直径 $3 \mathrm{~cm}$, 高さ $6 \mathrm{~cm}$ の円柱 体と, $15 \times 15 \times 15 \mathrm{~cm}$ の立方体の 2 種類とした. 生駒産 の単位体積重量は $25.8 \mathrm{kN} / \mathrm{m}^{3}$, 一軸圧縮強度は $60 \sim 90$ $\mathrm{MPa}$ であり, 一方, 稲田産の単位体積重量は 25.8 


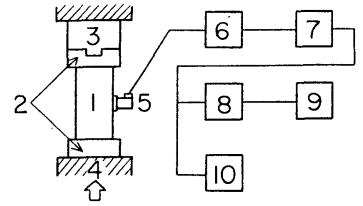

I. SPECIMEN

2. LOADING PLATE

3. LOAD CELL

6. PRE-AMPLIFIER

7. DISCRIMINATOR

8. DUAL COUNTER

4. RAM

9. RECORDER

5. AE TRANSDUCER IO.OSCILLOSCOPE

Fig. 1 Block diagram of AE apparatus.

$\mathrm{kN} / \mathrm{m}^{3}$ ，一軸圧縮強度は $80 \sim 100 \mathrm{MPa}$ であった。供試 体のサンプル数は生駒産, 稲田産とも円柱供試体 100 個, 立方供試体 20 個であった。

実験装置の概略をFig. 1 に示す. 実験において測定さ れる量は，一軸圧縮試験の際の軸圧と軸ひずみおよび供 試体が軸圧を受けた際に発生する AE である. Fig. 1 に おいて, $\mathrm{AE}$ 検出器で検出された信号はプリアンプとメ インアンプ(ディスクリミネーターに内蔵)で増幅され, ディスクリミネーターに装備されたフィルターと振幅弁 別器で信号処理が行われたのち, パルス化されてカウン ターで計数される.なお, フィルターは $\mathrm{AE}$ 検出器（共 振周波数 $140 \mathrm{kHz}$ の圧電素子) の特性を生かすため, $100 \mathrm{kHz} \sim 200 \mathrm{kHz}$ のバンドパスフィルターに形成した. また，スレショルドレベルは，5種類の組合せで予備実 験を行い，とらえられる $\mathrm{AE}$ 数は異なっても， $\mathrm{AE}$ 累積 曲線の変曲点は変わらないことを確かめたので, 先行軸 応力以下の応力で発生する $\mathrm{AE}$ が高レベルのスレショ ルドレベル以下になるよう低レベル $V_{L}$ を $380 \mathrm{mV}$, 高 レベルの $V_{H}$ を $400 \mathrm{mV}$ とした.これによって包絡線検 波された信号は $V_{H}$ を越えたのち，その包絡線が $V_{L}$ 以 下になれば 1 つのイベント・パルスとして観測されるこ とになる。なお，載荷試験は応力制御方式で 9.8 $\mathrm{MPa} / \mathrm{min}$ で行い, また, 供試体の軸ひずみは供試体の 中央部分の表面に貼りつけた 2 枚のひずみゲージ（一軸 ゲージ, 長さ $30 \mathrm{~mm}$ ) により計測した.

$\mathrm{AE}$ 計測を行ううえで注意しなければならない事柄の 1 つとしてノイズの除去がある.一般にノイズには, 計 測器自体から発生する電気的なものや八ムノイズ等があ る.これらのノイズは適当なアースを施すことによって 処理した.このほかに, 載荷試験機の載荷板と供試体上 下端面との不整な接触によるノイズがある。この研究で は, この接触によるノイズは供試体の両端面に薄いスポ ンジを敷くことによって除去することができた．その検 証をした例が Fig. 2 と Fig.3である．これらの図は，円 柱供試体に $14.7 \mathrm{MPa}$ の軸応力を 10 回の繰返し載荷に よって与え, その後 $29.4 \mathrm{MPa}$ まで単調載荷したとき の応力と軸ひずみおよび $\mathrm{AE}$ 累計数の関係を示したも

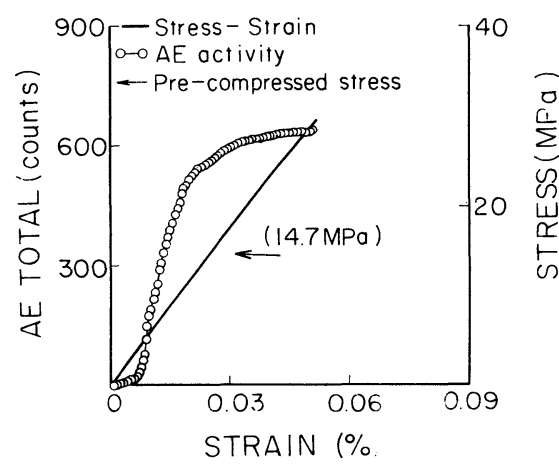

Fig. 2 Relationships among stress, strain and $\mathrm{AE}$ activity obtained without sponge pads between loading plates and specimen.

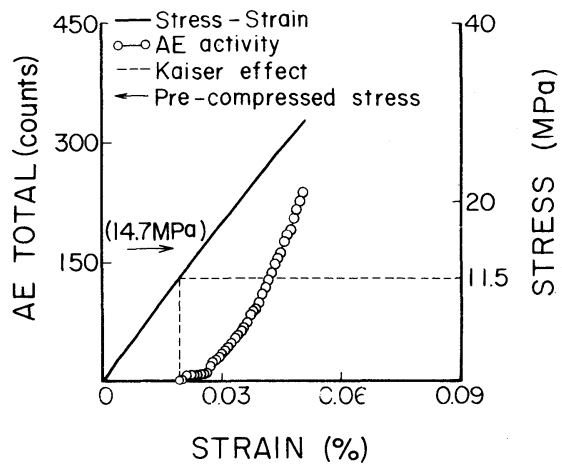

Fig. 3 Relationships among stress, strain and AE activity obtained with sponge pads between loading plates and specimen.

のである. Fig. 2 はスポンジを敷かない場合で, 載荷直 後より連続的に AE が発生している. 一方, Fig. 3 は供 試体の上下端面にスポンジを敷いた場合で, 与えられた 先行軸応力付近までは $\mathrm{AE}$ の発生はみられない，スポ ンジを敷くことによってノイズが除去できるのは，いず れの供試体でも Fig. 3 の例と同様であるが, 供試体自体 にマクロなクラックがある場合は供試体端面以外からも 載荷直後から AE が出るので Fig. 3のようにはならな い.そのため供試体にクラックなどの不連続部がない限 り，端面の不整により発生するノイズはスポンジを敷く ことによって完全に除去できることがわかる.

また，供試体のよ゙のあたりから $\mathrm{AE}$ が多く発生して いるかを調べるために, $\mathrm{AE}$ 検出器を供試体の上部, 中 央部，下部に設置して観測結果を比較した．その結果， 従来から報告 ${ }^{5}$ されているように，供試体中央部に設置 した場合 $\mathrm{AE}$ 検出器の応答が最も顥著に現われた. し たがって, 今回の実験では, $\mathrm{AE}$ 検出器を Fig. 1 で示す ように，供試体中央部に置く一点観測方式とした. 


\section{3. 実験とその結果の考察}

地山から採取した岩石試料を用いて，岩盤が地中で受 けていた地圧を $\mathrm{AE}$ のカイザー効果を利用して求める 場合，原位置の岩盤は，三次元応力状態下にあり，長時 間にわたり地盤応力を受けてクリープはほぼ完了し，ひ ずみの増加がほとんど終了している状態と思われる，岩 石は載荷を受けると，ひずみはしだいに増加しついに増 加が停止するが，ひずみの増加が停止した状態をここで はひずみ飽和状態と定義することにする.室内において, ひずみ飽和状態を作り出す方法には長期間のクリープ載 荷もあるが，それに代わる方法として，ここでは同一荷 重による繰返し載荷法を用いた。この方法によれば，同 一荷重を残留ひずみの増加が認められなくなるまで繰返 し載荷した状態を，ひずみ飽和状態とする。一方ひずみ 飽和状態への繰返し載荷途中で載荷を中止した供試体の 状態をひずみ不飽和状態と称することとする．このよう にして作成した両種の試料を用いて，AEのカイザー効 果から求められる先行軸応力がどのようになるかを比較 した。実験した項目は次のようである。なお，現地より 採取整形したままの各試料の先行応力を一軸圧縮試験の 際のカイザー効果を利用して推定した結果, 先行応力の 最大值は生駒産で $8.08 \mathrm{MPa}$ ，稲田産で $7.58 \mathrm{MPa}$ で あった

1）実験 I 円柱供試体に一定軸応力の繰返し載荷 を与え，残留ひずみの増加が認められなくなった状態， すなわちひずみ飽和状態とした供試体と残留ひずみの増 加がなお進行中の状態，すなわちひずみ不飽和状態の場 合の 2 つの状態の供試体について AE のカイザー効果 から求めた先行軸応力を比較した。

2）実験 II Fig.4（a ）の立方供試体に大きさの 異なる 2 方向の絽返し軸応力 $(X$ 方向 : $9.8 \mathrm{MPa}, Y$ 方向：14.7 MPa， $Z$ 方向は繰返し応力は無載荷）を順 次与えて, ひずみ飽和状態とひずみ不飽和状態の供試体 を作り, それぞれの供試体のカイザー効果から $X$ 方向 と $Y$ 方向のそれぞれの先行軸応力を求めて比較した.
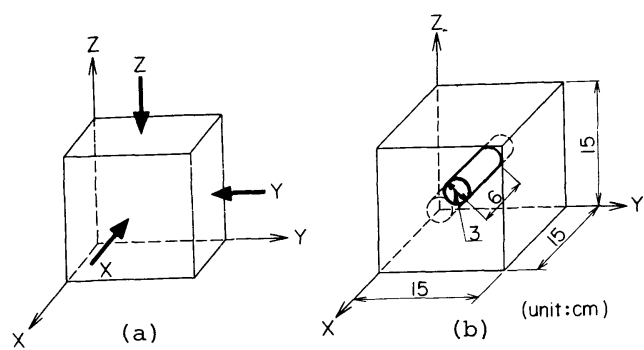

Fig. 4 (a) Cubic specimen of $15 \times 15 \times 15 \mathrm{~cm}$ and directions of stresses applied

( b ) Cylindrical specimen cored from cubic specimen

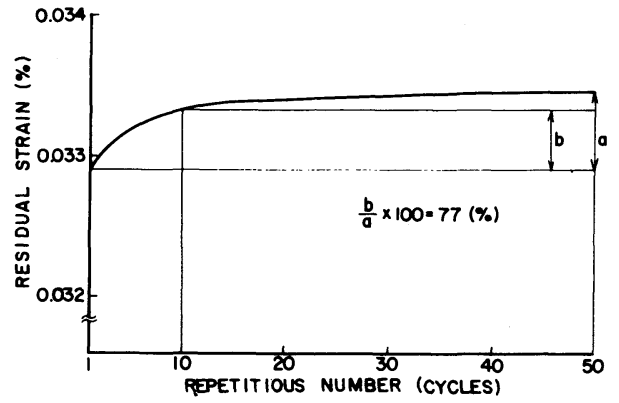

Fig. 5 Relationship between residual strain and repetitious number.

3）実験 III Fig.4（a ）の立方供試体に大きさの 異なる 3 方向の繰返し軸応力（ $X$ 方向：9.8 MPa， $Y$ 方向：14. $7 \mathrm{MPa}, Z$ 方向：19.6 MPa) を順次与え, 各方向ともひずみ飽和状態とした供試体における各方向 の先行軸応力をカイザー効果から求めて比較した.また, 上述した 3 方向ともひずみ飽和状態とした立方供試体の 中央部から Fig. 4 （b ）に示すように $X$ 方向を軸とす る円柱供試体を切り出し，その円柱供試体の先行軸応力 をカイザー効果から求めた.

\section{(1) 実倹 Iの結果と考察}

供試体直径 $3 \mathrm{~cm}$, 高さ $6 \mathrm{~cm}$ の円柱供試体に 14.7 $\mathrm{MPa}$ の絽返し軸応力を 50 回与えると残留ひずみの増 加がほとんど認められなくなったので，この場合をひず み飽和状態とした。 また，ひずみ飽和状態への絽返し載 荷途中のものとして繰返し回数 10 回の供試体をひずみ 不飽和状態の試料とした。そそのときの残留ひずみの増加 と繰返し回数の関係を Fig. 5 に示す. 図よりみれば, 1 回目の除荷時の残留ひずみを除いた繰返し 10 回におけ る残留ひずみの量（Fig.5 の b) はひずみ飽和とみなし た 50 回の繰返し載荷の残留ひずみから 1 回目の残留ひ ずみを除いた量 $\mathrm{a} の$ 約 $77 \%$ になっていた。なお，50回 の繰返し載荷後の残留ひずみの量（約 $0.0334 \%$ ）は同 種の花崗岩をひずみの増加が止まるまでクリープ (その 期間約 7 日）させたときの残留ひずみ量とほぼ等しかっ た.

上述の方法で作成したひずみ飽和状態とひずみ不飽和 状態の供試体に, 応力制御方式で応力を単調増加させて 一軸圧縮試験を実施し，同時に $\mathrm{AE}$ の観測を行い，応 力-軸ひずみ-AE 累積数関係を表わしたのが Fig. 6 であ る. 図より, 繰返し回数が 10 回（ひずみ不飽和状態） では，与えた軸応力が $14.7 \mathrm{MPa}$ であるにもかかわら ずカイザー効果より求めた先行軸応力は $12.6 \mathrm{MPa}$ と なり, かなり低い値となっていた。一方, 繰返し回数 50 回（ひずみ飽和状態）の供試体では，与えた軸応力 14.7 MPa に対し, カイザー効果を利用して求めた先行 

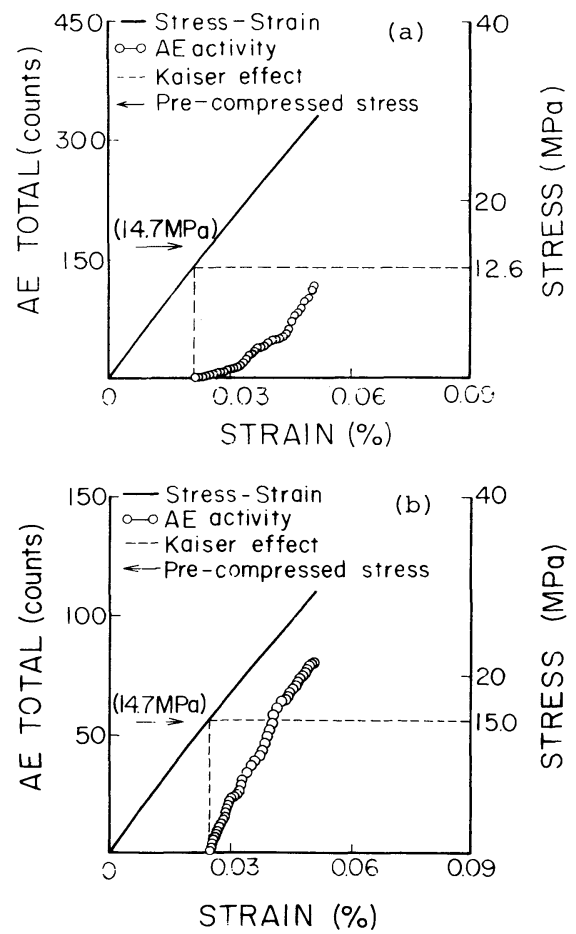

Fig. 6 Relationships among stress, strain and AE activity on a specimen subjected to cyclic compressive stress of (a) 10 cycles and ( b ) 50 cycles.

軸応力は $15.0 \mathrm{MPa}$ となっていた。したがって $\mathrm{AE} の$ カイザー効果を利用して先行軸応力を求める場合，少な くともひずみ飽和状態の供試体でなければ正確な值を求 めることができないことが確かめられた。ここに挙げた 試料は生駒産の花崗岩についての一例であるが，稲田産 においても同様な結果が得られた。

\section{（2）実験 Пの結果と考察}

Fig. 4 (a ) に示した，大きさ $15 \times 15 \times 15 \mathrm{~cm}$ の立方 供試体に大きさの異なる 2 方向の応力 $(X$ 方向 $: 9.8$ $\mathrm{MPa}, Y$ 方向 : $14.7 \mathrm{MPa}, Z$ 方向：繰返し応力は無 載荷）を順次繰返し載荷によって与え， $X, Y$ 両方向 とも 10 回の繰返しと 50 回の繰返しの違いが $\mathrm{AE}$ の力 イザー効果より求められる先行軸応力にビのような影響 をもたらすかを調べた。まず，立方供試体の $X$ 方向に $9.8 \mathrm{MPa}$ の応力で繰返し載荷を 10 回行い, 供試体を $90^{\circ}$ 回転させて $Y$ 方向に $14.7 \mathrm{MPa}$ で 10 回の繰返し載 荷を行ったのち, 再び $X$ 方向に供試体の軸の向きを変 えて $X$ 方向の応力を $9.8 \mathrm{MPa}$ 以上 $11.6 \mathrm{MPa}$ まで単 調に増加させた。その結果, 応力-軸ひずみ-AE 累積数 関係を示したのが Fig.7（a ）である. 図より， $X, Y$ それぞれの方向に与えた繰返し載荷の軸応力が 9.8 $\mathrm{MPa}$ と $14.7 \mathrm{MPa}$ であるにもかかわらず $X$ 方向の載荷
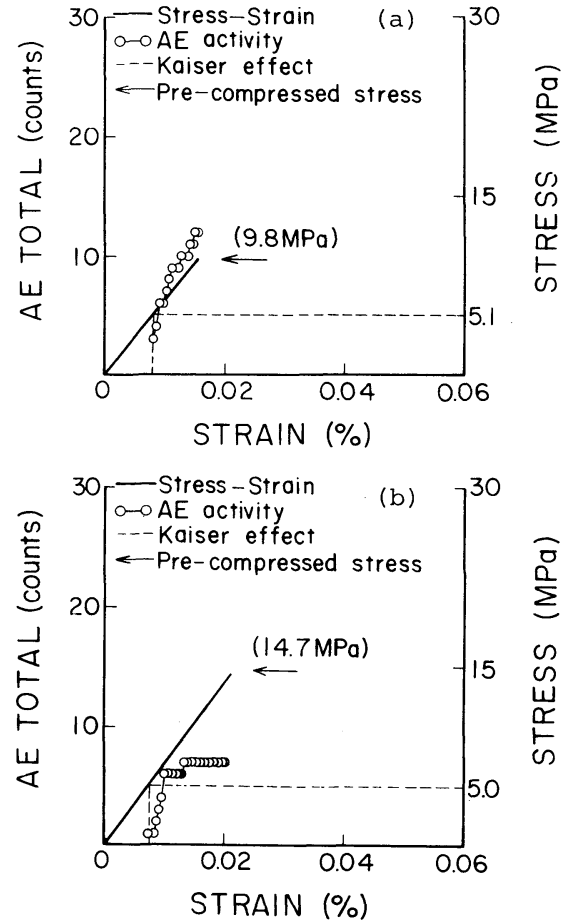

Fig.7 Relationships among stress, strain and $\mathrm{AE}$ activity on a specimen subjected to cyclic compressive stress of 10 cycles

(a) pre-compressed stress of $9.8 \mathrm{MPa}$

(b ) pre-compressed stress of $14.7 \mathrm{MPa}$

で得られた $\mathrm{AE}$ のカイザー効果より求めた $X$ 方向の先 行軸応力は $5.1 \mathrm{MPa}$ であった．次に供試体軸を $Y$ 方向 に向きを変え $16.7 \mathrm{MPa}$ まで単調載荷を行ってカイ ザー効果よりY方向の先行軸応力を求めた結果は Fig.7（b ）のように5.0 MPaであった.このことは, Fig. 5 に示した供試体への載荷の際, 残留ひずみの増進 がみられる段階（ひずみ不飽和状態）で載荷を終えたこ とにも一因があると考えられる。

一方，上述のような載荷順序でひずみ飽和状態とした 供試体を用いた場合のカイザー効果は， $X$ 方向につい てはFig.8（a）のように 10.0 MPaにおいて，また $Y$ 方向についてはFig. 8 （b ） が示すように 14.2 MPa か ら $\mathrm{AE}$ の発生がみられ， $X, Y$ 両方向とも与えた軸応 力付近から $\mathrm{AE}$ が発生しており，カイザー効果から推 定される先行軸応力は $X, Y$ 両方向ともそれぞれの方 向に与えた軸応力を $2 \sim 3 \%$ の誤差範囲で推定すること ができている．ゆえに AE のカイザー効果から各方向 の先行軸応力を求めるには, 上述の実験のように, 各方 向の残留ひずみの状態がともにひずみ飽和状態の試料で あることが必要であることがわかる。

\section{（3）実験皿の結果と考察}



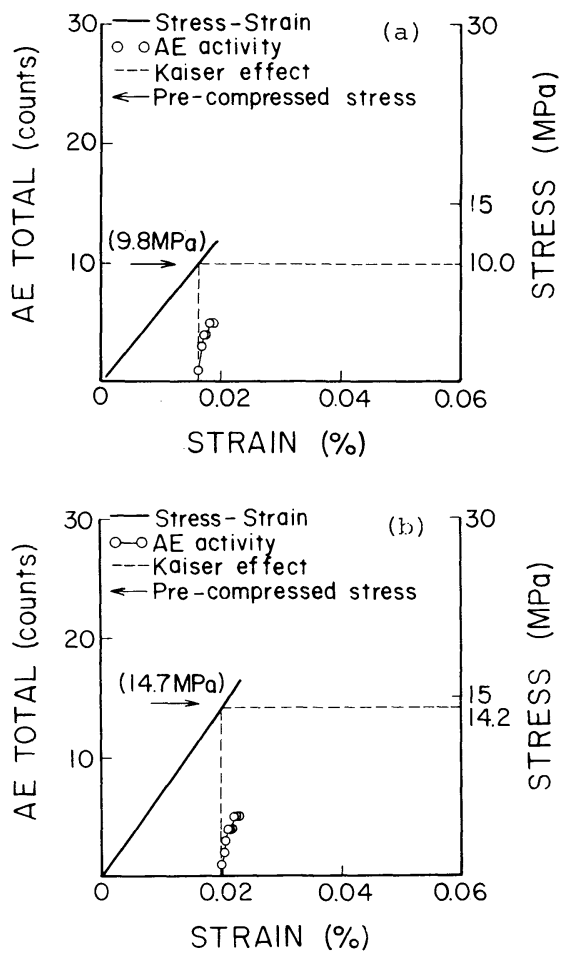

Fig. 8 Relationships among stress, strain and AE activity on a specimen subjected to cyclic compressive stress of 50 cycles

(a) pre-compressed stress of $9.8 \mathrm{MPa}$

(b) pre-compressed stress of $14.7 \mathrm{MPa}$

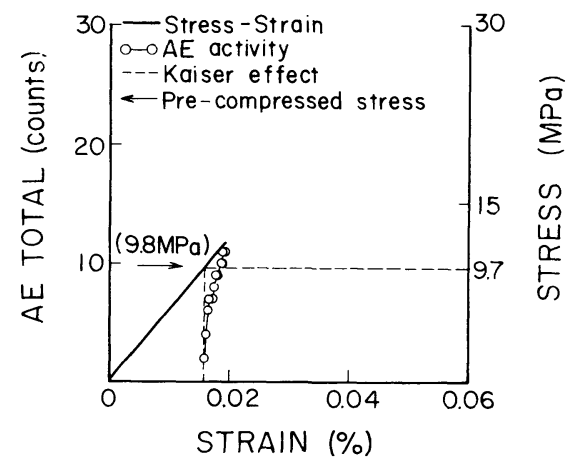

Fig. 9 Relationships among stress, strain and $\mathrm{AE}$ activity in $X$ direction of specimen subjected to 3 principal stresses.

次に大きさの異なる 3 方向の軸応力を別々に与えたひ ずみ飽和状態の供試体の各方向に与えた軸応力が $\mathrm{AE}$ のカイザー効果から推定される先行軸応力とどのような 関係にあるかを調べた．大きさ $15 \times 15 \times 15 \mathrm{~cm}$ の立方 供試体に, Fig. 4 （a ）のように $X$ 方向に $9.8 \mathrm{MPa}$, $Y$ 方向に $14.7 \mathrm{MPa}$ そして $Z$ 方向に $19.6 \mathrm{MPa}$ の応力

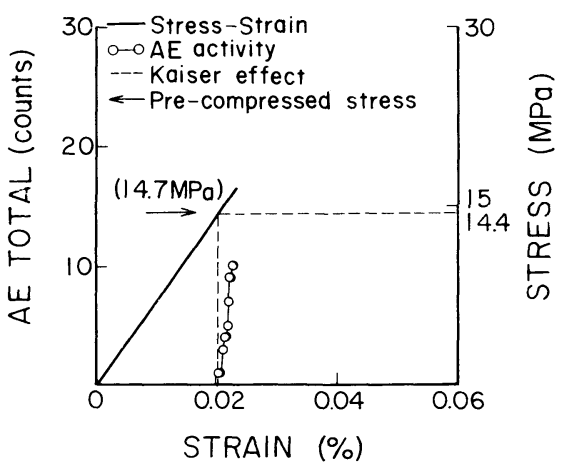

Fig. 10 Relationships among stress, strain and $\mathrm{AE}$ activity in $Y$ direction of specimen subjected to 3 principal stresses.

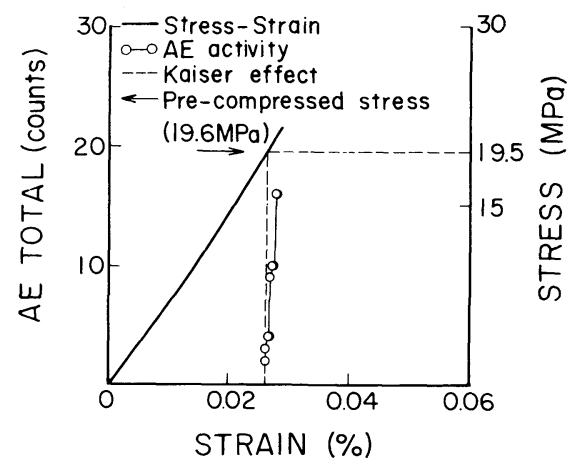

Fig. 11 Relationships among stress, strain and AE activity in $Z$ direction of specimen subjected to 3 principal stresses.

Table 1 Comparison between applied stresses and estimated stresses by the Kaiser effect.

\begin{tabular}{|c|c|c|c|}
\hline & X力向 & $\mathrm{Y}$ 方向 & ZJj) \\
\hline $\begin{array}{l}\text { A 、絽返し50回により } \\
\text { 与えた沈力 }\end{array}$ & $\begin{array}{l}9.8 \\
(\mathrm{MPa})\end{array}$ & $\begin{array}{l}14.7 \\
(\mathrm{MPa})\end{array}$ & $\begin{array}{l}19.6 \\
(\mathrm{MPa})\end{array}$ \\
\hline $\begin{array}{l}\text { B. カイザー効果より } \\
\text { 得られた行応力 }\end{array}$ & $\begin{array}{l}9.7 \\
(\mathrm{MPa})\end{array}$ & $\begin{array}{l}14.4 \\
(\mathrm{MPa})\end{array}$ & $\begin{array}{l}19.5 \\
(\mathrm{MPa})\end{array}$ \\
\hline C. 證差 $\left[C=100 *\left(1-\frac{B}{A}\right)\right] \%$ & $1.0 \%$ & $2.0 \%$ & $0.5 \%$ \\
\hline
\end{tabular}

を50回の繰返し載荷によって順次与えた.そののち， この供試体の $X$ 方向に再び $11.6 \mathrm{MPa}$ まで応力を単調 載荷したときの応力-軸ひずみ-AE 累積数の関係を示す と Fig.9 のようになる. 図よりカイザー効果から推定さ れる先行軸応力は $9.7 \mathrm{MPa}$ であり, この供試体の $X$ 方 向にあらかじめ与えた軸応力が $9.8 \mathrm{MPa}$ であることを 考えれば， $X$ 方向に関するカイザー効果より求められ る先行軸応力は他方向 $(Y: 14.7 \mathrm{MPa}, Z: 19.6 \mathrm{MPa})$ からの応力の影響を受けていないことがわかる．試験順 序を(方向：主応力値), 添字として繰返し回数の記号で, 


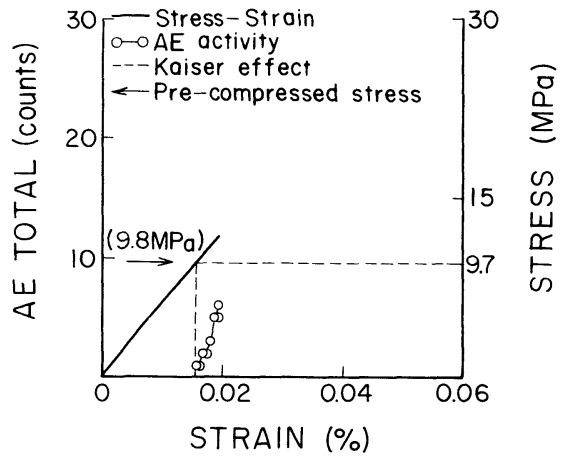

Fig. 12 Relationships among stress, strain and AE activity in cylindrical specimen cored from $X$ direction of cubic specimen subjected to 3 principal stresses.

また矢印を試験順序で略記することにし, 上記を記号化 すれば, $(X: 9.8)_{50} \rightarrow(Y: 14.7)_{50} \rightarrow(Z: 19.6)_{50} \rightarrow(X:$ $11.6)_{1}$ となる。同様に, $(X: 9.8)_{50} \rightarrow(Y: 14.7)_{50} \rightarrow(Z$ $: 19.6)_{50} \rightarrow(Y: 16.7)_{1}$ と $(X: 9.8)_{50} \rightarrow(Y: 14.7)_{50} \rightarrow(Z$ $: 19.6)_{50} \rightarrow(Z: 21.6)_{1}$ の場合の結果をそれぞれ Fig. 10, Fig. 11 に示す. Fig. 9〜11により得られた結果をまとめ ると Table 1 のようになる. Table 1 より, 各方向に初 期に与えられた軸応力は, 他方向へ全く影響しないこと がわかる．以上より残留ひずみが一定になるまで繰返し 載荷によって 3 方向の軸応力が与えられた供試体におい ては, カイザー効果を利用することにより，それぞれの 方向に与えた軸応力を約 $2 \%$ の誤差内で推定できる.

同様にひずみ飽和になるように，大きさの異なる 3 方 向の軸応力を順次繰返し与えた立方供試体の中央部から Fig. 4 (b ) のように円柱供試体 (直径 $3 \mathrm{~cm}$, 高さ $6 \mathrm{~cm}$ ) を切り出し, $X$ 方向の先行軸応力を求めたのが Fig. 12 である.Fig.12は, $(X: 9.8)_{50} \rightarrow(Y: 14.7)_{50} \rightarrow(Z:$ 19.6 $)_{50}$ の軸応力を受けた立方供試体の $X$ 方向を軸方向 として切り出した円柱供試体に $11.8 \mathrm{MPa}$ まで軸応力 を単調載荷したときの応力-軸ひずみ-AE 累積数の関係 を描いたものである．図より，カイザー効果から推定さ れる先行軸応力は $9.7 \mathrm{MPa}$ となっている. したがって, $X, Y, Z$ の各軸方向において残留ひずみがほぼ飽和し た試料では， $\mathrm{AE}$ のカイザー効果を利用することにより， その試料の各面に与えた軸応力を精度よく求めることが 可能であると考えられる. また, 他方向 $(Y, Z)$ から 切り出した試料においても同様な結果が得られた.なお, 図の例に示したサンプルはすべて生駒産であるが, 稲田 産の試料においても同様なことが認められた。

4. おわりに

種々な載荷方法であらかじめ軸応力を与えた花崗岩の
カイザー効果について得られた結果をまとめると以下の ようになる，なお，この報告においては，載荷中最初に $\mathrm{AE}$ が発生した応力を $\mathrm{AE}$ のカイザ一効果より求めた先 行軸応力とみなした。

（1）載荷時における載荷板と供試体端面との不整に よるノイズは, 供試体の両端面に薄いスポンジを敷くこ とによって除去できる.

（2）大きさの異なる軸応力を各面に繰返し載荷に よって与えた立方供試体においては，各軸応力方向にお いて残留ひずみが一定になるまで載荷が行われた供試体 （ひずみ飽和状態の場合）のみ，カイザー効果から載荷 方向ごとの先行軸応力を高い精度で見出すことができ る.これに対し，残留ひずみの増加がなお認められる状 態で載荷を中止した，いわゆるひずみ不飽和の供試体に おいては, $\mathrm{AE} よ り$ 求められる先行軸応力は当初与えた 軸応力よりも小さい値となる．このことより，花崗岩に おける $\mathrm{AE}$ のカイザー効果は，ひずみ飽和の程度に影 響していると考えてよい。

（3）上記（2）と同じ載荷方法で, 残留ひずみが定になるまで軸応力を繰返し与えた立方供試体の中央部 から一表面に垂直に円柱供試体を切り出し，この供試体 のカイザー効果から先行軸応力を推定した結果は, その 面に与えた軸応力の $1 \%$ の誤差内にあった.したがって， 載荷方向の岩石試料がひずみ飽和状態であれば，AEの カイザー効果を利用することによって，その載荷方向に 与えた軸応力を他の方向の載荷と無関係に精度よく推定 することが可能であるといえる。

最後に本研究を遂行するにあたり，(株) 大林組技術 研究所の藤原紀夫室長ならびに畑 浩二研究員から受け た援助に対してここに謝意を表する.

\section{参 考 文 献}

1) Obert, L. and Duvall, W. : Use of subaudible noises for the prediction of rock bursts, parts 2, U.S. Bureau of Mines, 1942.

2) Kaiser, J. : Untersuchungen über das Auffreten geraus chen beim zugversuch, Arkiv für das Eisenhuttenwesen, Vol. 24, pp. 43 45, 1953.

3) Goodman, R.E. : Subaudible noise during compression of rocks, Geol. Soc. Bull. Vol.74, pp. 487 490, 1963.

4）金川 忠・林 正夫・仲佐博裕：岩石における地圧成分 のアコースティック・エミッションによる推定の試み, 土木学会論文報告集，第 258 号, pp. 63〜 75, 1977.

5）楠ノ瀬勤一郎・西沢 修・伊藤久男・石土経士・長谷川 功：岩石の一軸圧縮試験における $\mathrm{AE}$ 発震機構, 地震, 第 34 巻，第 2 号, pp. 241 250，1981.

(1984.12.10・受付） 